\title{
Identification of Colourants and Varnishes in a 14th Century Decorated Wood-Carved Door of the Dionysiou Monastery in Mount Athos
}

\author{
Alexander Konstantas ${ }^{1}$, Ioannis Karapanagiotis ${ }^{2}$ (D) and Stamatis C. Boyatzis ${ }^{1, *(D)}$ \\ 1 Department of Conservation of Antiquities and Works of Art, University of West Attica, \\ 12243 Athens, Greece; alex.konstanta@gmail.com \\ 2 Department of Management and Conservation of Ecclesiastical Cultural Heritage Objects, \\ University Ecclesiastical Academy of Thessaloniki, 54250 Thessaloniki, Greece; y.karapanagiotis@aeath.gr \\ * Correspondence: sboyatzis@uniwa.gr
}

check for

updates

Citation: Konstantas, A.;

Karapanagiotis, I.; Boyatzis, S.C.

Identification of Colourants and

Varnishes in a 14th Century

Decorated Wood-Carved Door of the

Dionysiou Monastery in Mount

Athos. Coatings 2021, 11, 1087.

https://doi.org/10.3390/

coatings 11091087

Academic Editor:

Alessandro Pezzella

Received: 31 July 2021

Accepted: 27 August 2021

Published: 8 September 2021

Publisher's Note: MDPI stays neutral with regard to jurisdictional claims in published maps and institutional affiliations.

Copyright: (c) 2021 by the authors. Licensee MDPI, Basel, Switzerland. This article is an open access article distributed under the terms and conditions of the Creative Commons Attribution (CC BY) license (https:// creativecommons.org/licenses/by/ $4.0 /)$.

\begin{abstract}
A decorated and carved wooden door of the late Byzantine period (14th Century), which belongs to the Dionysiou Monastery in Mount Athos, Greece, constitutes an important relic of valuable technological information due to its construction technology and history. Seventeen (17) samples detached from the door are studied using optical microscopy, scanning electron microscopy (SEM) with energy dispersive X-ray analysis (SEM-EDX), and micro-Raman and FTIR spectroscopy. The following materials are identified in the cross sections of the door samples using micro-Raman spectroscopy: orpiment, lead white, red lead, red ochre, cinnabar, carbon black, gypsum, anhydrite, and calcite, and an organic colourant of the indigoid family. SEM-EDX studies supported to the aforementioned Raman results. Interestingly, a combination of inorganic and organic colourants was detected. The main goals of this particular study were to: (a) reveal the colour palette and materials, (b) identify the type of varnish and its condition, and (c) contribute to future restoration processes and aid conservators in selecting compatible restoration materials.
\end{abstract}

Keywords: 14th century; wood-carved; microscopy; Raman; SEM-EDX; FTIR; materials; pigments

\section{Introduction}

A decorated wood-carved door, in functional condition, located in the Church of Dionysiou Monastery of Mount Athos, has received attention due to its historical importance. According to sources [1], the door dates back to the 14th century, thus corresponding to the first period of the history of the Dionysiou Monastery. In this period, the monastery suffered from a severe fire incident, and the decorated door is among the few surviving objects from that first period. Moreover, the door panel is covered with a metal leaf on which a coloured, carved decoration, a rare and excellent example of Byzantine wood carving, is mounted.

The origins of the decoration's colourants/pigments from this particular period have only been briefly studied on some selected icons and relics [2-5]. The goal of the present report was to document and qualitatively analyse the materials used for the decoration of this door by applying microscopy and elemental and molecular analytical techniques, and also to assess their current condition as a result of past historical events. For this reason, seventeen (17) samples (sampling spots shown in Figure 1) were sampled and investigated. Attention was focused on the pigments, the varnish coating condition, and the related stratigraphy that could reveal more possible interventions or repairing/retouching actions.

The goals of the investigation were achieved using the following methods: (i) microRaman and SEM-EDX were employed to identify the pigments; (ii) FTIR was used to study the organic materials of the varnish layer; (iii) and finally, optical microscopy was applied to investigate sample stratigraphies. Consequently, the final goal of the study was 
to reveal the combinations of inorganic and organic materials, and, where possible, also their condition.

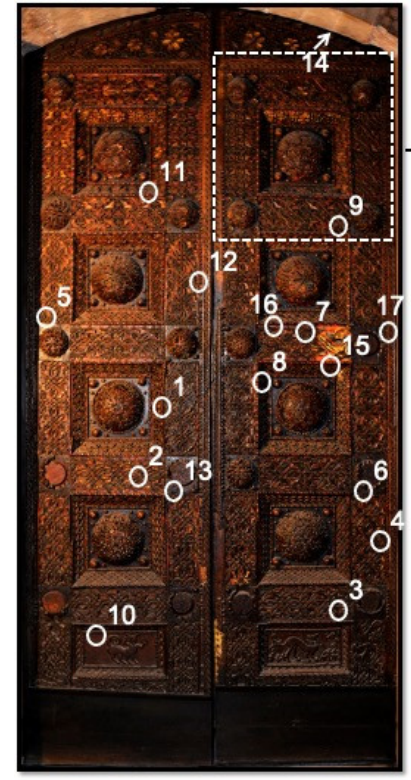

(a)

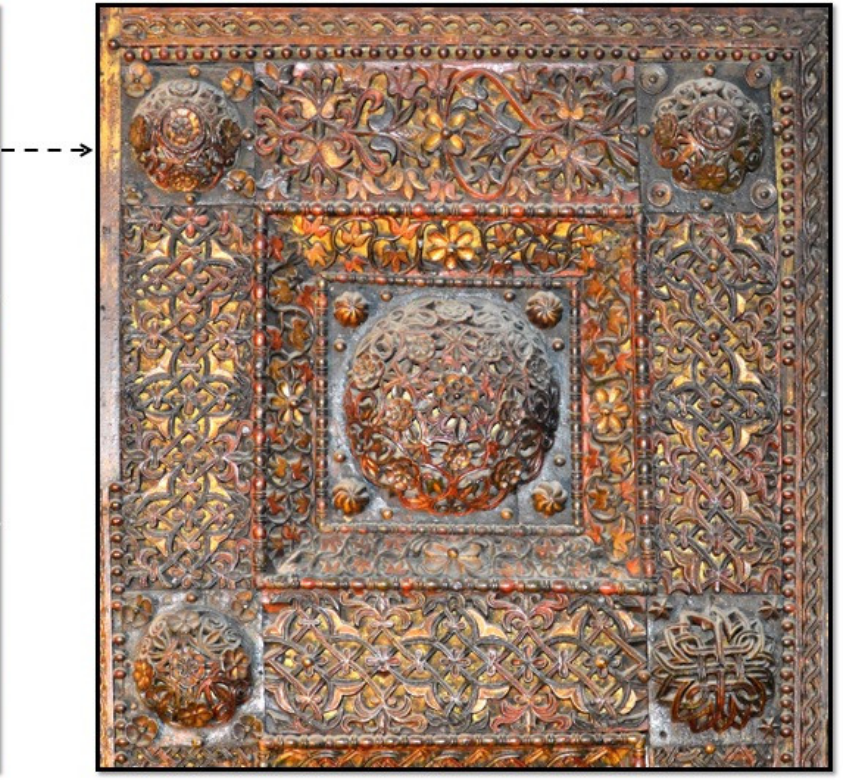

(b)

Figure 1. (a) Sampling spots and (b) detail from the decorated wood-carved door of the Church of Dionysiou Monastery in Mount Athos. Dimensions of each door leaf: $240 \mathrm{~cm} \times 60 \mathrm{~cm}$.

\section{Materials and Methods}

Aiming to investigate the apparently variable stratigraphy of the object, fifteen of the seventeen microsamples were taken from the artwork (sampling points shown in Figure 1), embedded in transparent polyester resin (Struers), and subsequently ground and polished using a Struers LaboPol-5 polishing, rotating table. The cross sections of the samples were then studied using optical microscopy, Raman and FTIR spectroscopies, and SEM-EDX scanning electron microscopy (SEM) with energy dispersive X-Ray analysis. Another two microsamples, which were scraps from the varnish layer, were extracted from the relic and subjected to FTIR analysis (samples 13 and 16).

Microsamples were studied using a Zeiss Axioskop 40 polarising light microscope equipped with a UV source, and by scanning electron microscopy (SEM; JEOL, JSM6510, Tokyo, Japan) with energy dispersive X-ray spectroscopy (EDX; Swift-ED, Oxford Instruments, High Wycombe, United Kingdom). For the SEM and SEM-EDX studies, samples were coated with a thin layer of carbon.

The micro-Raman spectra were obtained using a Renishaw Raman device (Renishaw, London, England) equipped with a microscope and a CCD detector. As a source of excitation, a diode laser with a radiant emission wavelength of $\lambda=785 \mathrm{~nm}$ was used. The beam size of the laser was of the order of $\sim 2 \mu \mathrm{m}$. The power density on the surface of the sample was $\sim 0.5 \mathrm{~mW} / \mu \mathrm{m}^{2}$ and the spectral resolution was $\sim 4 \mathrm{~cm}^{-1}$. Alignment and calibration of the spectrometer, before and after each measurement, was achieved by using a crystalline silicon $(\mathrm{Si})$ wafer.

Finally, the FTIR spectroscopy analyses were conducted so as to provide enhanced information. In particular, a Perkin-Elmer ${ }^{\circledR}$ model Spectrum 400 FT-IR spectrometer (PerkinElmer, Inc., Waltham, MA, USA) operating at the medium and near-infrared range was used. The spectra were collected with a spectral resolution of $4 \mathrm{~cm}^{-1}$, in the spectral range of $4000-450 \mathrm{~cm}^{-1}$ and 256 scans. The analysis was performed in diffuse reflectance mode with Perkin Elmer's special ' $\mathrm{KBr}$ pad' design involving a standard $\mathrm{KBr}$ disc holding the powder sample on its surface. 


\section{Results}

\subsection{Cross Section Analysis}

The investigation of the sample cross sections with optical microscopy revealed the various layers and provided the background for the subsequent spectroscopic study. In certain areas of the door, later interventions (overpaints) were revealed. The most interesting result was recorded in the samples D14 and D17 (shown in Figure 2 in visible-reflected and UV-fluorescence light, respectively), as two successive ground and painting layers (3,4 and 2,3 in Figure 2a-d, respectively) beyond the original painting layers ( 2 and 1 in Figure $2 \mathrm{a}-\mathrm{d}$, respectively) were observed in the microphotographs.

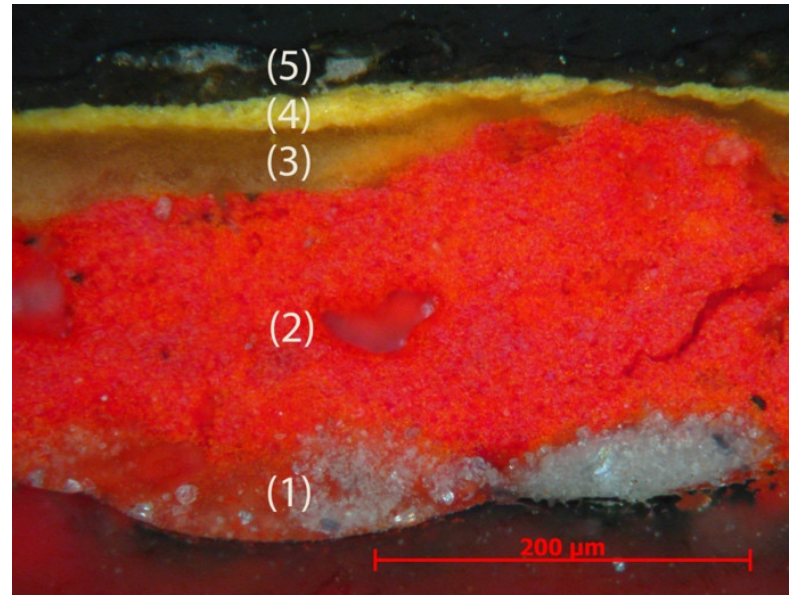

(a)

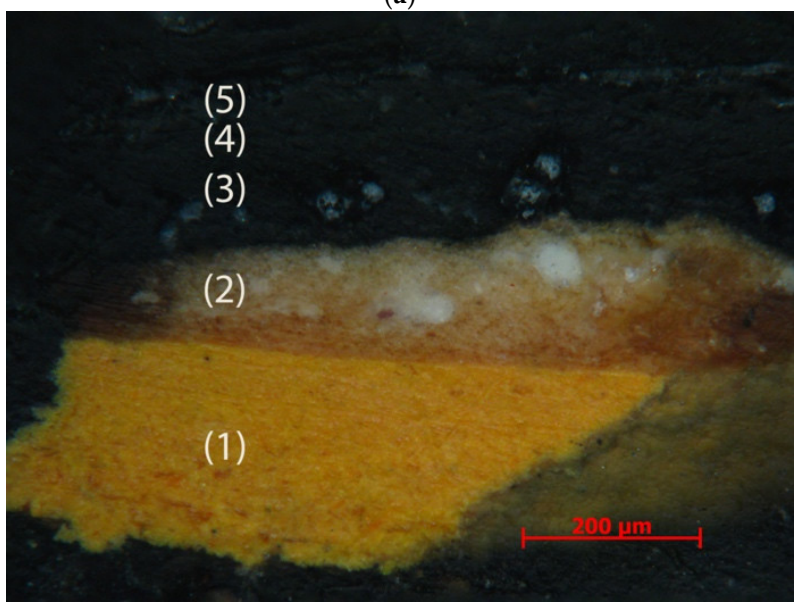

(c)

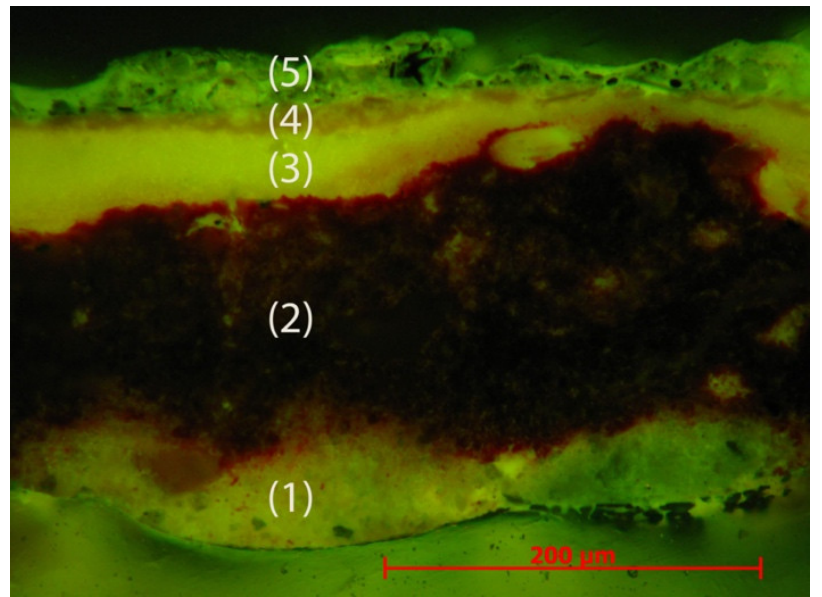

(b)

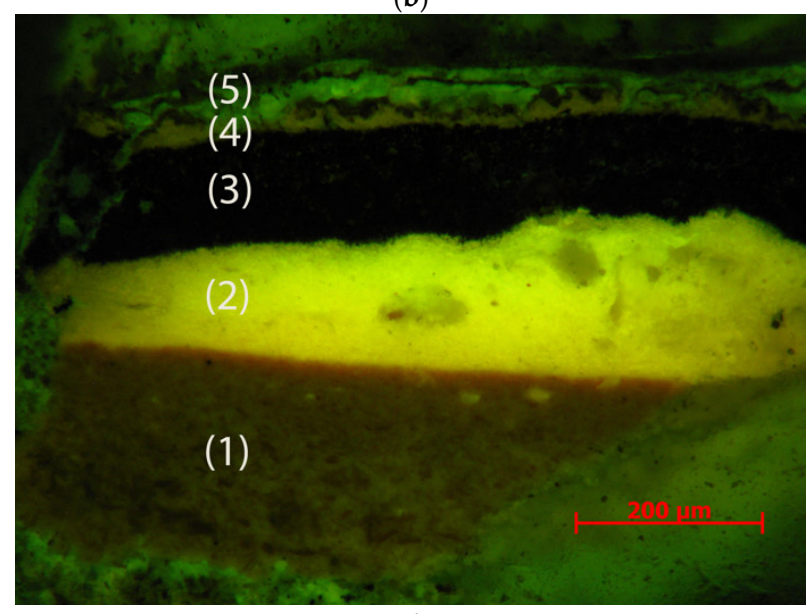

(d)

Figure 2. Sample cross sections D17 $(\mathbf{a}, \mathbf{b})$ and D14 (c,d). Cross sections in $(\mathbf{a}, \mathbf{c})$ visible-reflected light and (b,d) UV fluorescence $(\lambda \mathrm{exc}=365 \mathrm{~nm})$ are shown. Complete stratigraphy for $(\mathbf{a})$ and $(\mathbf{b})$ is as follows: (1) first layer of gesso ground: gypsum; (2) first painting layer: cinnabar and grains of carbon black; (3) second layer of gesso ground: gypsum; (4) second painting layer: orpiment; (5) varnish. For (c) and (d): (1) first painting layer: orpiment; (2) layer of gesso ground: gypsum, calcite, and orpiment; (3) second painting layer: carbon black; (4) first varnish layer; (5) second varnish layer.

As the varnish layer between the overpainted layer and the original layer (layer (2) and layer (3) in Figure 2a,b and layer (1) and (2) in Figure 2c,d) is not observed, it is concluded that the overpainted area corresponds to the same period of time and the same artist, and it is probably a redaction of the artist's final work.

The results of the microscopic, Raman, and EDX analyses are summarized in Table 1, which reveals the materials used in the layers of the sample cross sections. The extensive use of lead white is shown in the data of Table 1. 
Table 1. Cross sections of the samples. Pigments were identified using micro-Raman spectroscopy and SEM-EDX.

\begin{tabular}{|c|c|c|c|}
\hline Sample/Sampling Point & Stratigraphy & Raman Results & EDX Results \\
\hline \multirow{2}{*}{$\begin{array}{l}\text { D 1-Metal leaf } \\
\text { from decoration }\end{array}$} & Back side & - & $\mathrm{Cu}, \mathrm{Zn}$ \\
\hline & Front side & - & $\mathrm{Cu}, \mathrm{Zn}, \mathrm{Au}$ \\
\hline \multirow{4}{*}{ D 2-Yellow spot } & 1st painting layer & Orpiment & As, S, C, O \\
\hline & 1st varnish layer & - & - \\
\hline & Soot layer & Carbon black & $\mathrm{C}, \mathrm{O}$ \\
\hline & 2nd varnish layer & - & - \\
\hline \multirow{4}{*}{ D 3-Red spot } & Gesso ground & Gypsum & $\mathrm{Ca}, \mathrm{S}, \mathrm{C}, \mathrm{O}$ \\
\hline & 1st painting layer & Lead white & $\mathrm{Pb}, \mathrm{O}, \mathrm{C}$ \\
\hline & 2nd painting layer & Minium and lead white & $\mathrm{Pb}, \mathrm{O}, \mathrm{C}$ \\
\hline & Varnish layer & - & - \\
\hline \multirow{3}{*}{ D 4-Light blue spot } & 1st painting layer & $\begin{array}{c}\text { Indigo/woad, lead } \\
\text { white, red ochre, calcite, } \\
\text { and gypsum }\end{array}$ & $\mathrm{Ca}, \mathrm{S}, \mathrm{Pb}, \mathrm{C}, \mathrm{O}$ \\
\hline & 2nd painting layer & $\begin{array}{c}\text { Lead white, } \\
\text { indigo/woad, red ochre, } \\
\text { calcite, and gypsum }\end{array}$ & $\mathrm{Ca}, \mathrm{S}, \mathrm{Pb}, \mathrm{C}, \mathrm{O}$ \\
\hline & Varnish layer & - & - \\
\hline \multirow{6}{*}{ D 5-Light blue spot } & 1st painting layer & Lead white & $\mathrm{Pb}, \mathrm{Cu}, \mathrm{C}, \mathrm{O}$ \\
\hline & 2nd painting layer & $\begin{array}{l}\text { Indigo/woad, lead } \\
\text { white, red lead, } \\
\text { and calcite }\end{array}$ & $\mathrm{Pb}, \mathrm{Cu}, \mathrm{Ca}, \mathrm{C}, \mathrm{O}$ \\
\hline & 3rd painting layer & $\begin{array}{l}\text { Indigo/woad, lead } \\
\text { white and calcite }\end{array}$ & \\
\hline & 1st varnish layer & - & - \\
\hline & Soot layer & Carbon black & $\mathrm{C}, \mathrm{O}$ \\
\hline & 2nd varnish layer & - & - \\
\hline \multirow{5}{*}{ D 6-Blue spot } & Gesso ground & Gypsum & $\mathrm{Ca}, \mathrm{S}, \mathrm{C}, \mathrm{O}$ \\
\hline & 1st painting layer & Lead white & $\mathrm{Pb}, \mathrm{C}, \mathrm{O}$ \\
\hline & 2nd painting layer & $\begin{array}{l}\text { Indigo/woad, gypsum, } \\
\text { and lead white }\end{array}$ & $\mathrm{Pb}, \mathrm{Ca}, \mathrm{S}, \mathrm{C}, \mathrm{O}$ \\
\hline & 1st varnish layer & - & - \\
\hline & 2nd varnish layer & - & - \\
\hline \multirow{4}{*}{ D 7-Green spot } & 1st painting layer & Lead white & $\mathrm{Cu}, \mathrm{Pb}, \mathrm{C}, \mathrm{O}$ \\
\hline & 1st varnish layer & - & - \\
\hline & Soot layer & Carbon black & $\mathrm{C}, \mathrm{O}$ \\
\hline & 2nd varnish layer & - & - \\
\hline \multirow{4}{*}{ D 8-Light red spot } & 1st painting layer & Red lead and lead white & $\mathrm{Pb}, \mathrm{C}, \mathrm{O}$ \\
\hline & 1st varnish layer & - & - \\
\hline & Soot layer & Carbon black & $\mathrm{C}, \mathrm{O}$ \\
\hline & 2nd varnish layer & - & - \\
\hline \multirow{5}{*}{ D 9-Light blue spot } & 1st painting layer & Lead white & $\mathrm{Pb}, \mathrm{Cu}, \mathrm{C}, \mathrm{O}$ \\
\hline & 2nd painting layer & Lead white & $\mathrm{Pb}, \mathrm{Cu}, \mathrm{C}, \mathrm{O}$ \\
\hline & 1st varnish layer & - & - \\
\hline & Soot layer & Carbon black & $\mathrm{C}, \mathrm{O}$ \\
\hline & 2nd varnish layer & - & - \\
\hline
\end{tabular}


Table 1. Cont.

\begin{tabular}{|c|c|c|c|}
\hline Sample/Sampling Point & Stratigraphy & Raman Results & EDX Results \\
\hline \multirow{6}{*}{ D 10-Red spot } & Gesso ground & Gypsum & $\mathrm{Ca}, \mathrm{S}, \mathrm{C}, \mathrm{O}$ \\
\hline & 1st painting layer & Lead white & $\mathrm{Pb}, \mathrm{C}, \mathrm{O}$ \\
\hline & 2nd painting layer & Red lead & $\mathrm{Pb}, \mathrm{C}, \mathrm{O}$ \\
\hline & 1st varnish layer & - & - \\
\hline & Soot layer & Carbon black & $\mathrm{C}, \mathrm{O}$ \\
\hline & 2nd varnish layer & - & - \\
\hline \multirow{3}{*}{ D 11-Light blue spot } & 1st painting layer & Red lead & $\mathrm{Pb}, \mathrm{C}, \mathrm{O}$ \\
\hline & 2nd painting layer & $\begin{array}{l}\text { Indigo/woad and } \\
\text { lead white }\end{array}$ & $\mathrm{Pb}, \mathrm{C}, \mathrm{O}$ \\
\hline & Varnish layer & - & - \\
\hline \multirow{3}{*}{ D12-Red spot } & Gesso ground & Gypsum & $\mathrm{Ca}, \mathrm{S}, \mathrm{C}, \mathrm{O}$ \\
\hline & 1st painting layer & Cinnabar & $\mathrm{Hg}, \mathrm{S}, \mathrm{C}, \mathrm{O}$ \\
\hline & Varnish layer & - & - \\
\hline \multirow{6}{*}{ D 14-Black spot } & 1st painting layer & Orpiment & As, S, C, O \\
\hline & Gesso ground & $\begin{array}{l}\text { Gypsum, calcite, } \\
\text { and orpiment }\end{array}$ & $\mathrm{Ca}, \mathrm{S}, \mathrm{As}, \mathrm{C}, \mathrm{O}$ \\
\hline & 2nd painting layer & Carbon black & $\mathrm{C}, \mathrm{O}$ \\
\hline & 1st varnish layer & - & - \\
\hline & Soot layer & Carbon black & $\mathrm{C}, \mathrm{O}$ \\
\hline & 2nd varnish layer & - & - \\
\hline \multirow{3}{*}{ D 15-Green spot } & Gesso ground: & Gypsum and anhydrite & $\mathrm{Ca}, \mathrm{S}, \mathrm{C}, \mathrm{O}$ \\
\hline & 1st painting layer & $\begin{array}{l}\text { Orpiment, indigo/woad, } \\
\text { and anhydrite }\end{array}$ & $\mathrm{Ca}, \mathrm{S}, \mathrm{As}, \mathrm{C}, \mathrm{O}$ \\
\hline & Varnish layer & - & - \\
\hline \multirow{5}{*}{ D 17-Yellow spot } & 1st layer of gesso ground & Gypsum & $\mathrm{Ca}, \mathrm{S}, \mathrm{C}, \mathrm{O}$ \\
\hline & 1st painting layer & $\begin{array}{l}\text { Cinnabar and } \\
\text { carbon black }\end{array}$ & $\mathrm{Hg}, \mathrm{S}, \mathrm{C}, \mathrm{O}$ \\
\hline & $\begin{array}{l}\text { 2nd layer of } \\
\text { gesso ground }\end{array}$ & Gypsum & $\mathrm{Ca}, \mathrm{S}, \mathrm{C}, \mathrm{O}$ \\
\hline & 2nd painting layer & Orpiment & As, S, C, O \\
\hline & Varnish layer & - & - \\
\hline
\end{tabular}

\subsection{SEM-EDX Results}

Figures 3 and 4 are provided as examples of the SEM-EDX results. The identification of the elements in the designated spot of the SEM image is provided. The same analysis was carried out for all samples included in the study [6-12].

The detection of $\mathrm{Cu}$ and $\mathrm{Zn}$ in sample D1 (Figure 3) is indicative of a metal alloy [6] containing the above metals, where the small amount of gold $(\mathrm{Au})$ suggests that the particular metal leaf was gold-gilded (gold plated brass) [7]. The detection of As and S in sample D2 (Figure 4) shows the use of orpiment pigment by the artist [8,9]. Moreover, in samples D5, D7, and D9, the green pigment granules were investigated by SEM-EDX analysis, where copper was identified. Since luminescence prevented efficient Raman analysis in these pigments, further study is needed for more detailed identification. 


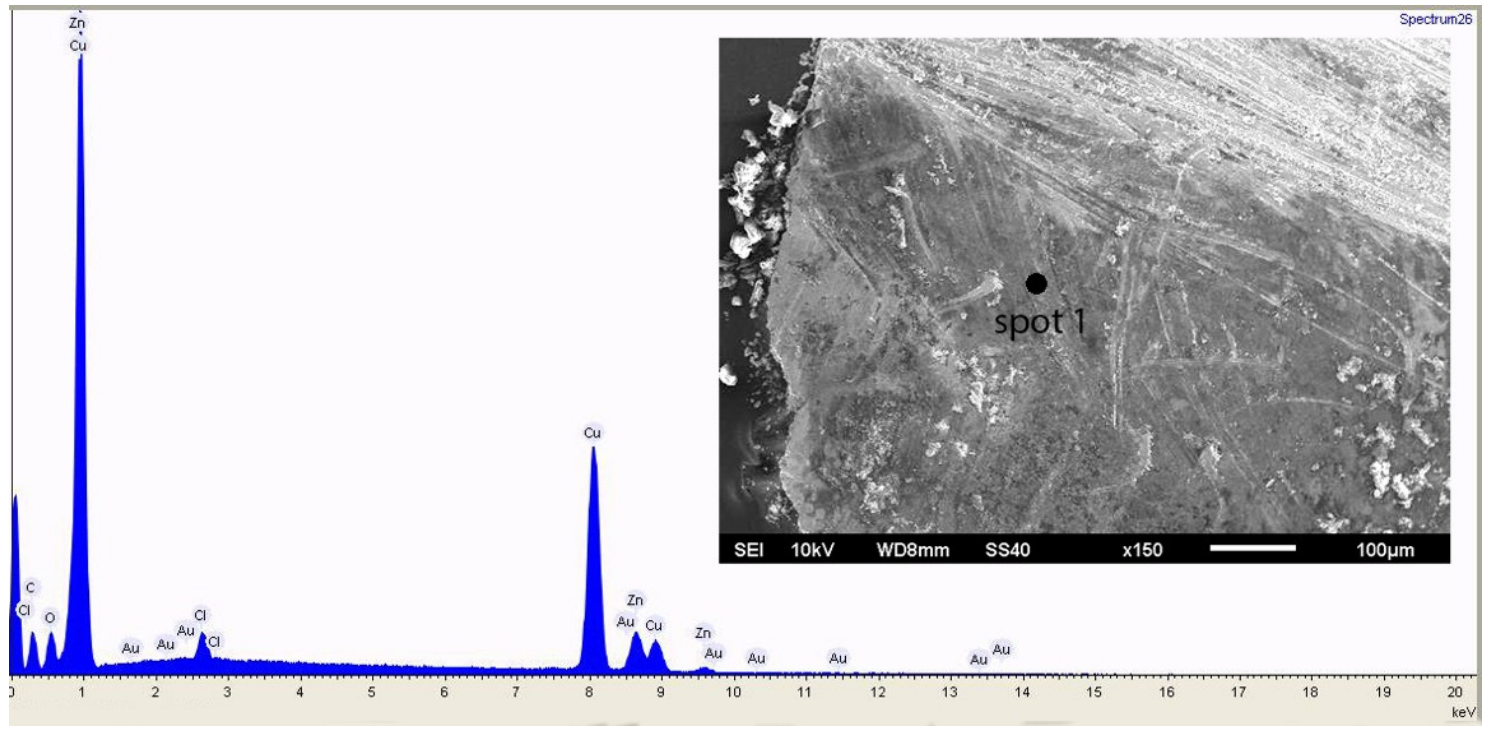

Figure 3. SEM image of the sample D1 and EDX spectrum of spot 1 in sample D1. Cu, Zn, and Au were identified.

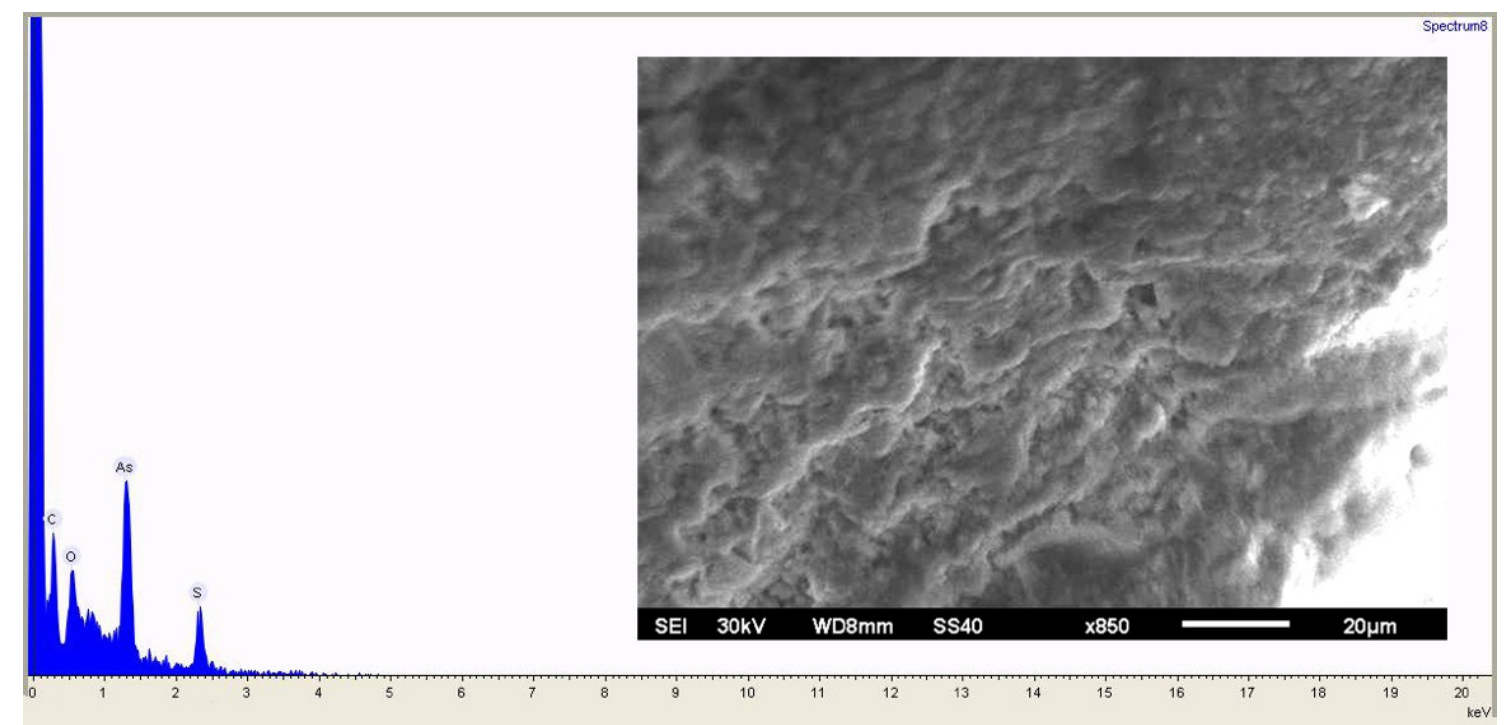

Figure 4. SEM image of the sample D2 and EDX spectrum. Elements of As and S were identified and confirm the Raman results, which revealed the presence of orpiment $\left(\mathrm{As}_{2} \mathrm{~S}_{3}\right)$.

\subsection{Raman Results}

Colourants and gesso ground materials identified in cross sections using micro-Raman spectroscopy are summarized in Table 2. Assignments of Raman peaks detected in the spectra are described next.

The Raman spectra of cinnabar displayed the characteristic strong band at $\sim 254 \mathrm{~cm}^{-1}$ as well as the two weak peaks at $\sim 284$ and $\sim 43 \mathrm{~cm}^{-1}$, which were attributed to the stretching vibrations of the $\mathrm{Hg}-\mathrm{S}$ bond [13-15].

In the Raman spectra of red ochre (hematite), the phonon modes of the pigment's octahedral structure at $\sim 225,295,408,498$, and $611 \mathrm{~cm}^{-1}$ were observed, as well as the broad high-energy overtone line at $\sim 1320 \mathrm{~cm}^{-1}[14,16]$.

Cross section analyses of samples D3 and D11 revealed the presence of red grains that consist of minium $\left(\mathrm{Pb}_{3} \mathrm{O}_{4}\right)$, according to the characteristic predominant Raman bands at $\sim 480$ and $550 \mathrm{~cm}^{-1}$, which are attributed to the stretching vibrations of the $\mathrm{Pb}-\mathrm{O}$ bonds of the $\mathrm{PbO}_{6}$ octahedra that are formed along the main symmetry axis of the structure [9]. Furthermore, three low-energy weak modes at $\sim 232,314$ and $391 \mathrm{~cm}^{-1}$ were recorded in 
the Raman spectrum, which involve vibrations of longer $\mathrm{Pb}-\mathrm{O}$ bonds interconnected by the above-mentioned chains of octahedra [17].

Table 2. Colourants identified in the investigated samples using micro-Raman spectroscopy. Characteristic peaks used for the identifications are included.

\begin{tabular}{|c|c|c|c|}
\hline Pigment & Sample & Composition & $\begin{array}{l}\text { Raman Characteristic Peaks and } \\
\text { Relative Intensities }{ }^{1}\left(\mathrm{~cm}^{-1}\right)\end{array}$ \\
\hline Orpiment & D1, D14, D15, D17 & $\mathrm{As}_{2} \mathrm{~S}_{3}$ & $\begin{array}{c}105 \text { m, } 136 \text { s, } 154 \text { s, } 179 \text { m, } 202 \text { s, } 293 \text { s, } \\
311 \text { vs, } 355 \text { vs, } 383 \text { m }\end{array}$ \\
\hline Lead white & $\begin{array}{l}\text { D3, D4, D5, D6, } \\
\text { D7, D8, D9, } \\
\text { D10, D11 }\end{array}$ & $2 \mathrm{PbCO}_{3} \cdot \mathrm{Pb}(\mathrm{OH})_{2}$ & 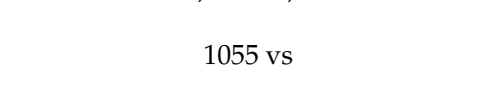 \\
\hline Minium & D3 & $\mathrm{Pb}_{3} \mathrm{O}_{4}$ & 232 w, 314 w, 391 w, 480 s, 550 vs \\
\hline Red ochre & $\mathrm{D} 4$ & $\mathrm{Fe}_{2} \mathrm{O}_{3}$ & $\begin{array}{c}225 \text { vs, } 295 \mathrm{~s}, 408 \mathrm{~m}, 498 \mathrm{w}, 661 \mathrm{vw}, \\
1320 \mathrm{~m} \text { and br }\end{array}$ \\
\hline Cinnabar & D12, D17 & $\mathrm{HgS}$ & $254 \mathrm{vs}, 285 \mathrm{w}, 343 \mathrm{~m}$ \\
\hline Indigo/woad & $\begin{array}{l}\text { D4, D5, D6, } \\
\text { D11, D15 }\end{array}$ & $\mathrm{C}_{16} \mathrm{H}_{10} \mathrm{~N}_{2} \mathrm{O}_{2}$ & $\begin{array}{c}547 \mathrm{w}, 600 \mathrm{w}, 942 \mathrm{w}, 1015 \mathrm{w}, 1147 \mathrm{~m}, \\
1253 \mathrm{~s}, 1313 \mathrm{w}, 1366 \mathrm{vs}, 1463 \mathrm{~m}, 1486 \mathrm{~m}, \\
1573 \mathrm{~s}, 1585 \mathrm{~s}, 1616 \mathrm{~s}, 1700 \mathrm{~s}\end{array}$ \\
\hline Carbon black & $\begin{array}{l}\text { D2, D5, D7, D8, } \\
\text { D9, D10, D14, D17 } \\
\text { D3, D4, D6, }\end{array}$ & $\mathrm{C}$ & $1318 \mathrm{~s}$ and br, $1584 \mathrm{vs}$ and br \\
\hline Gypsum & $\begin{array}{l}\text { D10, D12, D14, } \\
\text { D15, D17 }\end{array}$ & $\mathrm{CaSO}_{4} \cdot 2 \mathrm{H}_{2} \mathrm{O}$ & 1008 vs \\
\hline Anhydrite & D15 & $\mathrm{CaSO}_{4}$ & $1016 \mathrm{vs}$ \\
\hline Calcite & D4, D5, D14 & $\mathrm{CaCO}_{3}$ & $155 \mathrm{w}, 280 \mathrm{w}, 1088 \mathrm{vs}$ \\
\hline
\end{tabular}

${ }^{1}$ vs: very strong, s: strong, m: medium, w: weak, vw: very weak, br: broad, sh: shoulder.

The results in Table 1 reveal the extensive use of lead white; this pigment was identified in several samples. Lead white $\left(2 \mathrm{PbCO}_{3} \cdot \mathrm{Pb}(\mathrm{OH})_{2}\right)$ was identified through the characteristic peak at $1055 \mathrm{~cm}^{-1}$ in its Raman spectrum due to the $\mathrm{v}_{1}$, or the symmetric stretch vibration of $\mathrm{CO}_{3}{ }^{2-}$ [14].

Small black areas (granules) were revealed in the cross sections of several samples, which consisted of carbon black as observed in the appearance of a characteristic broad band at $\sim 1584 \mathrm{~cm}^{-1}$, assigned to a doubly degenerate deformation vibration of the aromatic ring and a second one at $\sim 1318 \mathrm{~cm}^{-1}$, and attributed to a crystalline size effect $[18,19]$.

Apart from the inorganic pigments described above, an organic blue indigoid colourant of plant origin was also detected, which can either be correlated with indigo (Indigofera tinctoria L. and other species) or woad (Isatis tinctoria L.). Its Raman spectrum (Table 1) showed the two weak, low-energy peaks at $\sim 547$ and $600 \mathrm{~cm}^{-1}$ that were assigned to the bending vibrational modes involving the central [-C=C-] coordinate [20]; a weak $\sim 942 \mathrm{~cm}^{-1}$ band due to the $\mathrm{C}-\mathrm{H}$ out-of-plane bending motion; the peaks at 1015 and $1147 \mathrm{~cm}^{-1}$, attributed to vibrations involving the $\mathrm{C}-\mathrm{H}$ in-plane bending; the 1313, 1463, 1486, 1573, and $1616 \mathrm{~cm}^{-1}$ spectral lines due to the $\mathrm{C}-\mathrm{C}$ stretching vibrations of the benzene rings; the band at $1585 \mathrm{~cm}^{-1}$, attributed to the in-phase stretching vibrations of the aromatic $\mathrm{C}=\mathrm{C}$ bonds; and finally, the considerably stronger three modes at $\sim 1253,1366$, and $1700 \mathrm{~cm}^{-1}$, which were assigned to $\mathrm{C}-\mathrm{H} / \mathrm{C}=\mathrm{O}$ bending, $\mathrm{N}-\mathrm{H} / \mathrm{C}-\mathrm{H}$ in-plane bending, and $\mathrm{C}=\mathrm{O} / \mathrm{C}=\mathrm{C}$ stretching vibrations, respectively $[20,21]$.

In several samples, calcite was detected within the painting layers, possibly as a filler/dispersing medium; its Raman spectrum showed the predominant band at $\sim 1088 \mathrm{~cm}^{-1}$, which was due to the $\mathrm{v}_{1}$ or the symmetric $\mathrm{CO}_{3}{ }^{2-}$ stretching vibration [21]. Moreover, the two low-energy weak peaks at 155 and $280 \mathrm{~cm}^{-1}$ included in the Raman spectrum of calcite arose from the external vibrations of the $\mathrm{CO}_{3}{ }^{2-}$ groups that involved translatory and rotatory oscillations of those groups within the crystal lattice mode [22]

Gypsum and anhydrite were detected in the gesso ground layers of samples D3, D10, D12, D14, D15, and D17. The Raman spectra of gypsum showed a strong peak at $1008 \mathrm{~cm}^{-1}$, which was attributed to the v1(a1) symmetric stretching vibration modes of $\mathrm{SO}_{4}{ }^{2-}$ tetrahedra [14]. Anhydrite $\left(\mathrm{CaSO}_{4},\right)$ is often found with gypsum, and a study of the 
Raman spectrum of the former showed that the band attributed to the symmetric stretch vibration v1(a1) $\mathrm{SO}_{4}{ }^{2-}$ appeared at approximately $1016 \mathrm{~cm}^{-1}$ [14].

The Raman spectra of orpiment $\left(\mathrm{As}_{2} \mathrm{~S}_{3}\right)$ displayed the characteristic strong bands at 136, 154, 202, 293, 311, and $355 \mathrm{~cm}^{-1}$. Each As atom was surrounded by three sulphur atoms, and each (S) atom was shared by two (As) atoms, while the layers were held together by van der Waals forces [23]. The region between 100 and $200 \mathrm{~cm}^{-1}$ were bands due to the S-As-S angle bending, while the one from approximately 300 to $400 \mathrm{~cm}^{-1}$ was the As-S stretching vibrations [24].

Figure 5 is shown as examples of the micro-Raman results. The identifications of pigments and their assignments in the sample's cross section D17 (Figure 2a,b), based on the photographs obtained using optical microscopy, are described in the figure caption. This type of analysis was carried out for all samples included in the study.

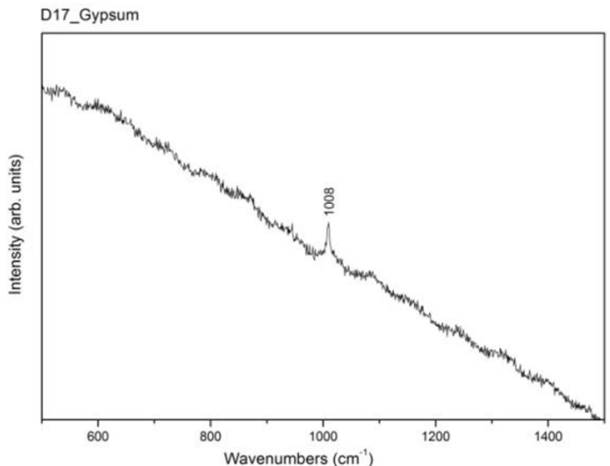

(a)

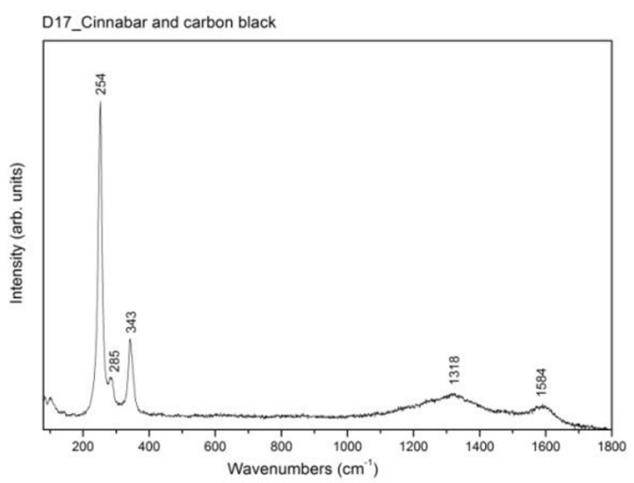

(c)

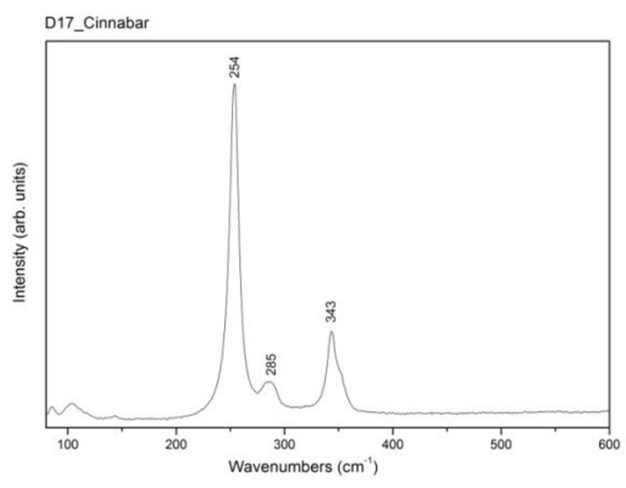

(b)

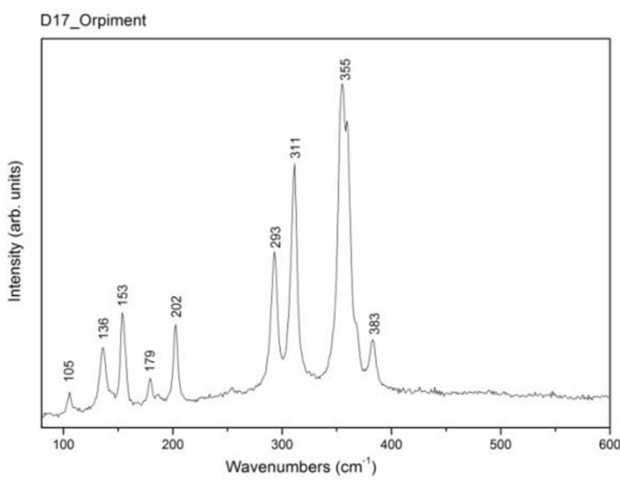

(d)

Figure 5. Four Raman spectra, which led to the identification of pigments and the gesso ground in the sample cross sections D17 (Figure 2a,b), are included as examples. In particular, the following were identified: (a) gypsum, (b) cinnabar, (c) carbon black with cinnabar, and (d) orpiment.

\subsection{FTIR Results}

Varnish samples were taken from two different spots of the door surface, sampling spots \#13 and \#16; their powder infrared spectra are shown in Figure 6.

In both samples, complex organic materials were detected, with natural resin (possibly mastic, a triterpenoid) being the most abundant common component, with strong maxima at $2956 / 2926 \mathrm{~cm}^{-1}$ and $2857 \mathrm{~cm}^{-1}$ (C-H stretching), $1738 / 1709 \mathrm{~cm}^{-1}$ (C=O stretch), $1458 \mathrm{~cm}^{-1}$ and $1384 \mathrm{~cm}^{-1}\left(\mathrm{CH}_{2}, \mathrm{CH}_{3}\right.$ bending vibrations), along with weaker ones at 1171 , $1124,1073,1040,952 \mathrm{~cm}^{-1}$ (generally, C-O stretch), and $744 \mathrm{~cm}^{-1}$ (C=C-H bend) [25-27]. Additionally, the relatively intense band at $848 \mathrm{~cm}^{-1}$ in sample D13 could also be assigned to aromatic C-H vibrations. The pronounced $2926 \mathrm{~cm}^{-1}$ component indicates additional material such as oil, or possibly another resin, while the feature at $1290-1280 \mathrm{~cm}^{-1}$ (stronger in sample D13) [28] could be assigned to aromatic ethers or phenolic moieties formed as a 
result of the heat shock. This, in combination with the weaker, typically aromatic bands at $3064(\mathrm{w}), 1608(\mathrm{sh}), 1513(\mathrm{w}) \mathrm{cm}^{-1}$, may account for the heat-induced aromatization of the triterpenoid resin $[29,30]$ on the object's surface [31,32]. This may occur according to the following reaction scheme [30], showing the aromatization of ring A of oleanolic acid, a typical mastic component (Figure 7).

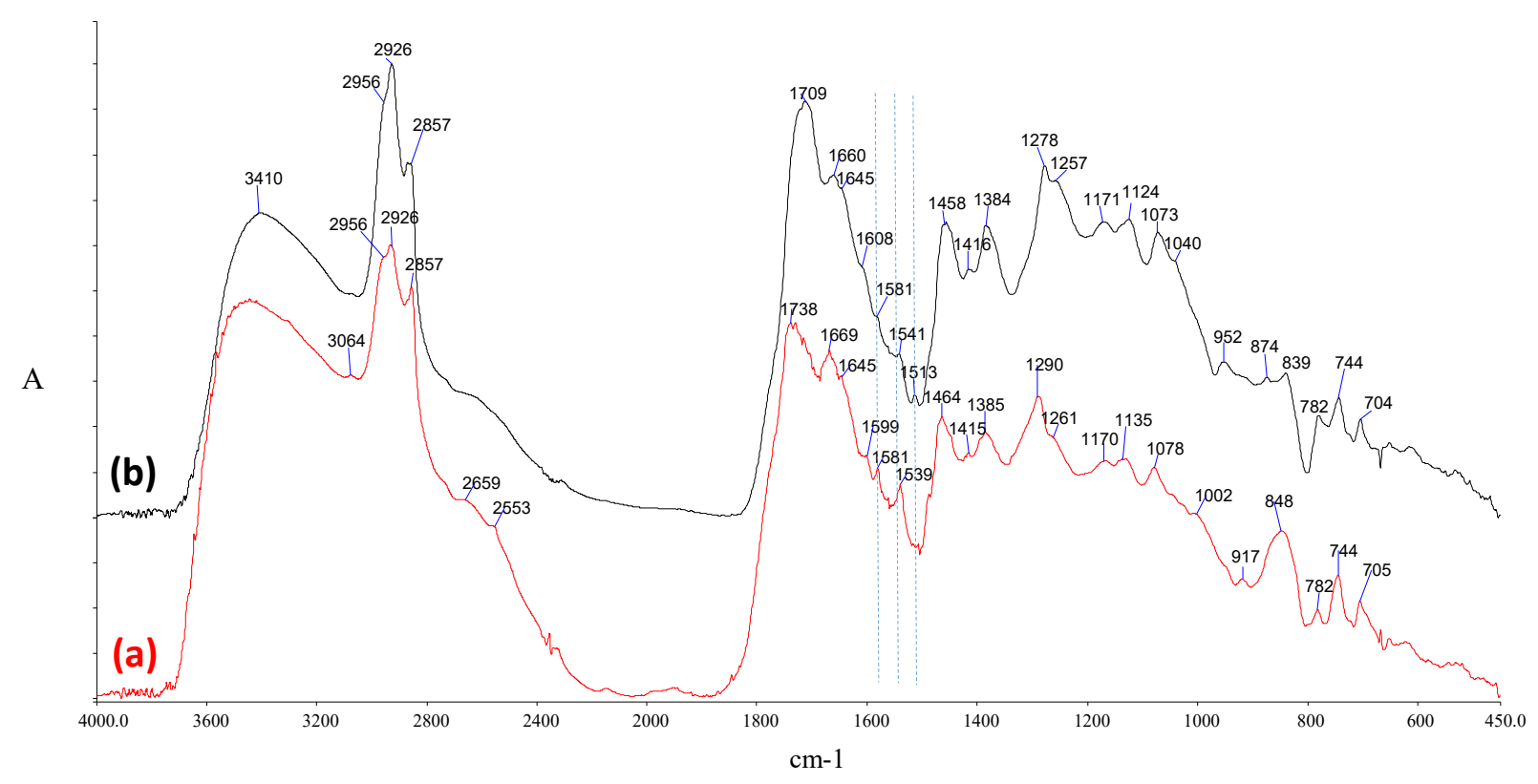

Figure 6. Infrared spectra of varnish powder samples; (a) D13 and (b) D16. Dashed vertical lines depict correspondence of aromatic and metal salt features between the two samples.

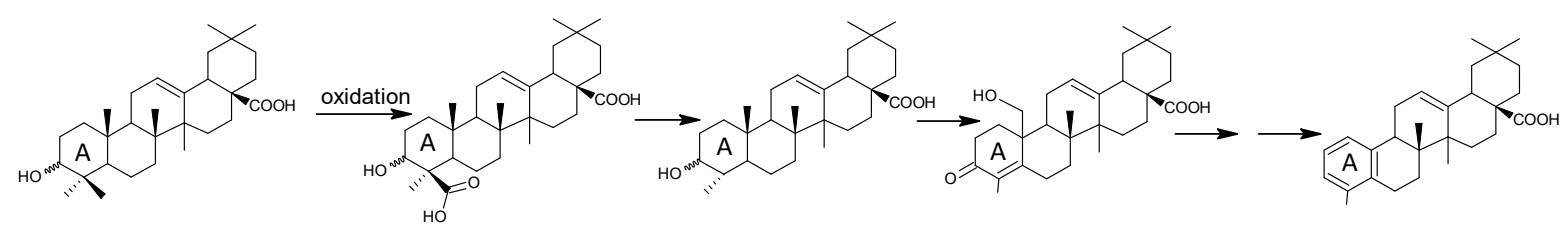

Figure 7. Possible oxidation route of oleanonic acid, a typical triterpenic mastic component leading to aromatic product (formation of aromatic ring A).

The weak but characteristic peaks observed at 1581 (sh), $1541 \mathrm{~cm}^{-1}$ (also stronger in sample D13) are indicative of the antisymmetric carboxylate vibration of metal salts [33-35], possibly due to interactions between $\mathrm{Pb}^{2+}$ and $\mathrm{Ca}^{2+}$ (due to lead white and gypsum, respectively, in the vicinity of the samples), and either the acidic fraction of the resin or a possible oil component, which, however, is not clearly detectable in the recorded spectra due to overlaps of its most prominent peaks (i.e., ester or acidic carbonyls and $\mathrm{C}-\mathrm{H}$ vibrations) by those of the resin material. More specifically, the maxima can be assigned to the antisymmetric stretch (or vas) of unidentate $\left(\sim 1580 \mathrm{~cm}^{-1}\right)$ and bidentate $\left(\sim 1540 \mathrm{~cm}^{-1}\right)$ calcium carboxylate complexes [33,36], while the weak peak at $1513 \mathrm{~cm}^{-1}$ (more prominent in sample \#16), where lead white is detected, can be assigned to the $v_{\text {as }}$ of lead carboxylate [37,38].

The heat shock experienced by the varnish layer first led to the significant softening of the material, allowing for metal ion migration through the layers and the consequent formation of metal salts with the acid resin components. 


\section{Conclusions}

Beyond its historical importance, including a documented fire incident [39] in 1535, the wood-carved door has a specific technological significance, which was investigated through this study. A striking feature of the door's decoration is the extended palette of inorganic and consecutive organic colourant layers, along with consecutive varnish layers; while in another sample from a nearby area, the alternating ground and pigment layers arguably suggested a correction at a later, unspecified time (samples D14 and D17).

The varnish samples showed a triterpenoid resin, possibly mastic, with added components (oil or other resin). Their infrared spectra showed signs of deterioration due to interactions of the acidic organic components, with the metal ions of pigments and the ground layer, and indications of heat-induced oxidations (aromatization); this may well be in accordance with the recorded history of the object involved in a fire incident.

As shown in Table 2, Raman spectra and SEM-EDX revealed the presence of a wide colourants palette, including yellow (orpiment), red (lead red, red ochre, and cinnabar), blue (indigo/woad), lead white, and carbon black; green could also be assigned to a copper pigment, although more evidence is needed. Furthermore, gypsum, anhydrite, and calcite were identified as the ground-layer materials in most samples.

As objects of the late Byzantine period have rarely been studied through multianalytical physicochemical approaches [2-4], the data of Table 2 can be considered as a reference point for researchers who are interested in having a broad view of the Byzantine painting palette and techniques.

Author Contributions: A.K. conceptualization; methodology; investigation; data curation; writing original draft; I.K. supervision; resources; data curation; writing - review and editing; S.C.B. supervision; funding acquisition; data curation; writing — review and editing. All authors have read and agreed to the published version of the manuscript.

Funding: This work has been funded through the Scholarship for Doctoral Candidates by the Special Account For Research Grants, University of West Attica.

Institutional Review Board Statement: Not applicable.

Informed Consent Statement: Not applicable.

Acknowledgments: We would like to acknowledge the Abbot of the Monastery of St. Dionysiou in Mount Athos, Archimandrite Petros, and all the brotherhood. In addition, George Fousteris for his contribution in the historical field of a particular study, and Dimitrios Karakatsanis for providing us with valuable photos of the artifact. Finally, the authors would like to thank the Research Committee and the Special Account for Research Grants of the University of West Attica for financially supporting Konstanta's PhD studies.

Conflicts of Interest: The authors declare no conflict of interest.

\section{References}

1. Kadas, S.N. Monastery of Saint Dionysios. Pilgrimage Guide (History-Art-Relics), 3rd ed.; Monastery of Saint Dionysios: Mount Athos, Greece, 2002; pp. 56-59.

2. Karapanagiotis, I.; Lampakis, D.; Konstanta, A.; Farmakalidis, H. Identification of colourants in icons of the Cretan School of iconography using Raman spectroscopy and liquid chromatography. J. Archaeol. Sci. 2013, 40, 1471-1478. [CrossRef]

3. Karapanagiotis, I.; Minopoulou, E.; Valianou, L.; Daniilia, S.; Chryssoulakis, Y. Investigation of the colourants used in icons of the Cretan School of iconography. Anal. Chim. Acta 2009, 647, 231-242. [CrossRef]

4. Valianou, L.; Wei, S.; Mubarak, M.S.; Farmakalidis, H.; Rosenberg, E.; Stassinopoulos, S.; Karapanagiotis, I. Identification of organic materials in icons of the Cretan School of iconography. J. Archaeol. Sci. 2011, 38, 246-254. [CrossRef]

5. Daniilia, S.; Andrikopoulos, K.S.; Sotiropoulou, S.; Karapanagiotis, I. Analytical study into El Greco's baptism of Christ: Clues to the genius of his palette. Appl. Phys. A 2008, 90, 565-575. [CrossRef]

6. Nusimovici, M.A.; Meskaou, A. Raman scattering by $\alpha$-HgS (Cinnabar). Phys. Stat. Sol. B 1973, 68, 121-125. [CrossRef]

7. Bell, I.M.; Clark, R.J.H.; Gibbs, P.J. Raman spectroscopic library of natural and synthetic pigments (pre -1850 AD). Spectrochim. Acta A 1997, 53, 2159-2179. [CrossRef]

8. Mazzocchin, G.A.; Agnoli, F.; Salvadori, M. Analysis of Roman age wall paintings found in Pordenone, Trieste and Montegrotto. Talanta 2004, 64, 732-741. [CrossRef] [PubMed] 
9. McCarty, K.F. Inelastic light scattering in a-Fe $\mathrm{O}_{3}$ : Phonon vs Magnon scattering. Solid State Commun. 1988, 68, 799-802. [CrossRef]

10. Vigouroux, J.P.; Husson, E.; Calvarin, G.; Dao, N.Q. Etude par spectroscopié vibrationnelle des oxydes $\mathrm{Pb}_{3} \mathrm{O}_{4}, \mathrm{SnPb}_{2} \mathrm{O}_{4}$ et $\mathrm{SuPb}\left(\mathrm{Pb}_{2} \mathrm{O}_{4}\right)_{2}$. Spectrochim. Acta Part A Mol. Spectrosc. 1982, 38, 393-398. [CrossRef]

11. Tuinstra, F.; Koenig, J.L. Raman spectrum of graphite. J. Chem. Phys. 1970, 53, 1126-1130. [CrossRef]

12. Nakamizo, M.; Kammereck, R.; Walker, P.L., Jr. Laser Raman studies on carbons. Carbon 1974, 12, 259-267. [CrossRef]

13. Tatsch, E.; Schrader, B. Near-infrared Fourier Transform Raman spectroscopy of indigoids. J. Raman Spectrosc. 1995, 26, 467-473. [CrossRef]

14. Withnall, R.; Shadi, I.T.; Chowdhry, B.Z. Case study: The analysis of dyes by SERRS. In Raman Spectroscopy in Archaeology and Art History; Edwards, H.G.M., Chalmers, J.M., Barnett, N.W., Eds.; The Royal Society of Chemistry: Cambridge, UK, 2005; pp. 152-166.

15. Gunasekaran, S.; Anbalagan, G.; Pandi, S. Raman and infrared spectra of carbonates of calcite structure. J. Raman Spectrosc. 2006, 37, 892-899. [CrossRef]

16. Morimoto, N. The crystal structure of orpiment $\left(\mathrm{As}_{2} \mathrm{~S}_{3}\right)$ refined. Mineral. J. 1954, 1, 160-169. [CrossRef]

17. Forneris, R. The infrared and Raman spectra of realgar and orpiment. Am. Mineral. 1969, 54, 1062-1074.

18. Türker, M.C.Z.; Kısasöz, A.; Guler, K. Experimental Research on Properties of Naval Brass Castings. Prac. Metallogr. 2016, 53, 24-35. [CrossRef]

19. Sandu, I.; Murta, E.; Neves, E.; Pereira, M.; Sandu, A.V.; Kuckova, S.; Maurício, A. A comparative interdisciplinary study of gilding techniques and materials in two Portuguese Baroque "talha dourada" complexes. Estud. Conserv. Restauro 2013, 1, 47-71. [CrossRef]

20. Vermeulen, M.; Sanyova, J.; Janssens, K. Identification of artificial orpiment in the interior decorations of the Japanese tower in Laeken, Brussels, Belgium. Herit. Sci. 2015, 3, 9. [CrossRef]

21. Ogalde, J.P.; Salas, C.O.; Lara, N.; Leyton, P.; Paipa, C.; Vallette, M.C.; Arriaza, B. Multi-instrumental identification of orpiment in archaeological mortuary contexts. J. Chil. Chem. Soc. 2014, 59, 2571-2573. [CrossRef]

22. Rodríguez, S.L.; López, V.; Miguel, L.C. Microscopic Identification of Vine Black Pigment In A Tempera Painting By Francisco De Goya. SM Anal. Bioanal. Tech. 2017, 2, 1-8. [CrossRef]

23. Tanevska, V.; Nastova, I.; Minčeva-Šukarova, B.; Grupče, O.; Ozcatal, M.; Kavčić, M.; Jakovlevska-Spirovska, Z. Spectroscopic analysis of pigments and inks in manuscripts: II. Islamic illuminated manuscripts (16th-18th century). Vib. Spectrosc. 2014, 73, 127-137. [CrossRef]

24. Gómez, B.; Parera, S.; Siracusano, G.; Maier, M. Integrated analytical techniques for the characterization of painting materials in two South American polychrome sculptures. E-Preserv. Sci. 2010, 7, 1-7.

25. Theodorakopoulos, C. The Excimer Laser Ablation of Picture Varnishes. Ph.D. Thesis, Royal College of Art, London, UK, 27 May 2005.

26. Ménager, M.; Azémard, C.; Vieillescazes, C. Study of Egyptian mummification balms by FT-IR spectroscopy and GC-MS. Microchem. J. 2014, 114, 32-41. [CrossRef]

27. Nevin, A.; Comelli, D.; Osticioli, I.; Toniolo, L.; Valentini, G.; Cubeddu, R. Assessment of the ageing of triterpenoid paint varnishes using fluorescence, Raman and FTIR spectroscopy. Anal. Bioanal. Chem. 2009, 39, 2139-2149. [CrossRef]

28. Azémard, C.; Vieillescazes, C.; Ménager, M. Effect of photodegradation on the identification of natural varnishes by FT-IR spectroscopy. Microchem. J. 2014, 112, 137-149. [CrossRef]

29. Bruni, S.; Guglielmi, V. Identification of archaeological triterpenoid resins by the non-separative techniques FTIR and 13C NMR: The case of Pistacia resin (mastic) in comparison with frankincense. Spectrochim. Acta Part A Mol. Biomol. Spectrosc. 2014, 121, 613-622. [CrossRef]

30. Neilson, A.H.; Hynning, P. Polycyclic aromatic hydrocarbons: Products of chemical and biochemical transformation of Alicyclic precursors. Toxicol. Environ. Chem. 1996, 53, 45-89. [CrossRef]

31. Tirat, S. Propriétés Physico-Chimiques et Vieillissement des Vernis huile de lin/Colophane: De la Technique du Luthier à la Conservation des Instruments de Musique Vernis. Ph.D. Thesis, Universite De Cergy-Pontoise, Cergy-Pontoise, France, 8 December 2017.

32. Tirat, S.; Degano, I.; Echard, J.P.; Lattuati-Derieux, A.; Lluveras-Tenorio, A.; Arul, M.; Serfaty, S.; Huero, J.Y. Historical linseed oil/colophony varnishes formulations: Study of their molecular composition with micro-chemical chromatographic techniques. Microchem. J. 2016, 126, 200-213. [CrossRef]

33. Otero, V.; Sanches, D.; Montagner, C.; Vilarigues, M.; Carlyle, L.; Lopes, J.; Melo, M. Characterisation of metal carboxylates by Raman and infrared spectroscopy in works of art. J. Raman Spectrosc. 2014, 45, 11-12. [CrossRef]

34. Ma, X.; Beltran, V.; Ramer, G.; Pavlidis, G.; Parkinson, D.; Thoury, M.; Meldrum, T.; Centrone, A.; Berrie, B. Revealing the Distribution of Metal Carboxylates in Oil Paint from the Micro- to Nanoscale. Angew. Chem. 2019, 131, 11778-11782. [CrossRef]

35. Hermans, J.J. Metal Soaps in Oil Paint: Structure, Mechanisms and Dynamics. Ph.D. Thesis, Van ‘ $t$ Hoff Institute for Molecular Sciences (HIMS), University of Amsterdam, Amsterdam, The Netherlands, 9 May 2017.

36. Nakamoto, K. Infrared and Raman Spectra of Inorganic and Coordination Compounds, Part B, Applications in Coordination, Organometallic, and Bioinorganic Chemistry, 6th ed.; John Wiley \& Sons: Hoboken, NJ, USA, 2009; pp. 64-65. 
37. Plater, M.J.; De Silva, B.; Gelbrich, T.; Hursthouse, M.; Higgitt, C.; Saunders, D. The characterisation of lead fatty acid soaps in "protrusions" in aged traditional oil paint. Polyhedron 2003, 22, 3171-3179. [CrossRef]

38. Catalano, J.; Yao, Y.; Murphy, A.; Zumbulyadis, N.; Centeno, S.A.; Dybowski, C. Analysis of Lead Carboxylates and LeadContaining Pigments in Oil Paintings by Solid- State Nuclear Magnetic Resonance. MRS Online Proc. Libr. 2014, 1656, $371-379$. [CrossRef]

39. Kadas, S.N. The Notes of the Manuscripts of the Monastery of Dionysios of Mount Athos; Monastery of Saint Dionysios: Mount Athos, Greece, 1996; pp. 64-67. 